\title{
Brittleness modeling of Cambay shale formation for shale gas exploration: a study from Ankleshwar area, Cambay Basin, India
}

\author{
Ravinder Ariketi $^{1} \cdot$ Uttam K. Bhui $^{2} \cdot$ Sushil Chandra $^{1} \cdot$ Samir Biswal $^{1}$
}

Received: 13 March 2016/ Accepted: 25 January 2017/Published online: 3 March 2017

(c) The Author(s) 2017. This article is published with open access at Springerlink.com

\begin{abstract}
Unconventional gas shales are described as organic-rich, fine-grained reservoirs and are typically dominated by clays. The shale gas reservoirs have received great attention in the past decade, because of their large reserves as well as recent technical advances in developing these resources. Accordingly, there are increasing demands to understand the petrophysical and mechanical properties of these gas shale rocks. The mineral composition and the presence of organic matter can influence not only the distribution of pores and fluid saturation, but also the effectiveness of stimulation. The geomechanical study of a shale gas reservoir is useful in identifying the intervals which can be fractured effectively. The estimation of geomechanical properties from well logs and their calibration with laboratory-derived properties on cores has been attempted in the present paper for Cambay shale of Cambay Basin, India, which is very much prospective for shale gas exploration. Powder X-ray diffraction (XRD) analysis was carried out on drill cutting samples in the study area, and it was seen that the major mineralogy is quartz, kaolinite, pyrite, calcite and mixed clays. Petrographic observation and Fourier transform infrared spectroscopy (FTIR) results also conform to the same minerals which are identified from XRD. Geomechanical properties (Young's modulus, Poisson's ratio, brittleness) of Cambay shale derived from sonic logs and density logs and are validated
\end{abstract}

Ravinder Ariketi

ravigeo786@gmail.com

1 Gujarat State Petroleum Corporation Ltd., Gandhinagar, Gujarat 382010, India

2 School of Petroleum Technology, Pandit Deendayal Petroleum University, Raisan, Gandhinagar, Gujarat 382007 , India with the available predicted brittleness index (BI) from mineralogy through petrographic observation, XRD and FTIR interpretation results. Modeling using petrel software with $\log$ data and P-impedance was carried out and a relation between log results and P-impedance volume was established. The study concluded that (BI) varies from 0.44 (less brittle) to 0.75 (highly brittle) using both mineralogy and sonic logs. This study successfully identified the areas of high BI in the study area which can be an input for effective stimulation for shale gas exploration and exploitation.

Keywords Shale oil/gas reservoir · Brittleness index (BI) · $\mathrm{X}$-ray diffraction $(\mathrm{XRD}) \cdot$ Fourier transform infrared spectroscopy (FTIR) · Cambay shale · Cambay Basin

\section{Introduction}

Characterizing organic-rich shales can be challenging as these rocks vary in lithological behavior. Horizontal drilling and hydraulic stimulation have made hydrocarbon production from organic-rich shales economically viable. Identification of zones to drill a horizontal well and to initiate or contain hydraulic fractures requires use of elastic and mechanical properties.

The rock mechanical properties like Poisson's ratio, Young's modulus and brittleness of the rock play an important role to decide the completion type and fracture intervals and productivity. These two components (Poisson's ratio and Young's modulus) together are the reflection of the rocks ability to fail under stress and fracture. Brittle oil/gas shale's are more likely to get fractured and will respond better to hydraulic fracturing treatment. Quantification of brittleness index (BI) combined Poisson's 
ratio and Young's modulus of rock mechanical properties in shale is necessary in identification of favorable zones for hydro fracturing.

Gamma ray, neutron porosity and resistivity logs are useful to characterize the reservoir. This additional information can come from the integration of specialized logging tools and core laboratory measurements. The availability of seismic data (P-impedance), X-ray diffraction (XRD) data, Fourier transform infrared spectroscopy (FTIR) data and dipole sonic, density logs enable characterization of a shale gas reservoir in terms of its mineral content and elastic properties.

\section{Background Geology}

Cambay Basin is a narrow, NNW-SSE trending intracratonic rift basin, formed at the end of cretaceous which is located on western margin of the Indian shield (Fig. 1). The basin, around $425 \mathrm{~km}$ long with an average width of about $138 \mathrm{~km}$, extends from Luni river in the north to Tapti river in the south having five tectonic blocks (Fig. 1). The Cambay Basin covers an area of about 59,000 sq km. It lies between the west and northwestern margin of Indian shield between latitudes $21^{\circ} \mathrm{N}$ to $25^{\circ} \mathrm{N}$ and longitudes $71^{\circ} 15^{\prime} \mathrm{E}$ to $73^{\circ} 30^{\prime} \mathrm{E}$ in the states of Gujarat and Rajasthan.

The Cambay shale formation (henceforth CSF) unconformably overlies the Olpad formation from lower to middle Eocene. The thickness of the formation varies widely from $50-70 \mathrm{~m}$ in the northern part over the Mehsana horst to more than 500-2500 in Hazira, Broach, Tarapur and Patan depressions. The CSF has been divided into two units - the lower (older) Cambay shale and the upper (younger) Cambay shale on the basis of a log marker (neck marker)_-separated by an erosional unconformity. The Lower Cambay shale is dark gray, thin-bedded, fissile, carbonaceous and slightly calcareous with rare occurrences of pyrite, whereas the upper Cambay shale is from black, massive and soft to moderately hard, fissile, silty, pyritic, non-calcareous and carbonaceous (Sarraf et al. 2000; Chowdhary 2004; Sharma et al. 2004; Mishra and Patel 2011).

The study area is situated in Narmada tectonic block of south Cambay Basin. The area of study covers $160 \mathrm{sq} \mathrm{km}$ in which CSF varies in thickness from $25 \mathrm{~m}$ in east to $700 \mathrm{~m}$ in west (Fig. 1). The top of Cambay shale occurs at $1100 \mathrm{~m}-2200 \mathrm{~m}$. The lithology of the CSF is mainly carbonaceous shale, clay stone with intercalations of siltstones.

\section{Methodology}

Four wells (namely well no 1, 2, 3 and 4) were drilled through CSF are considered for the study. Sonic logs, DTC and DTS recorded in all the four wells are used for estimating rock mechanical properties. Mineralogical study was done with the help of petrographic observation of the

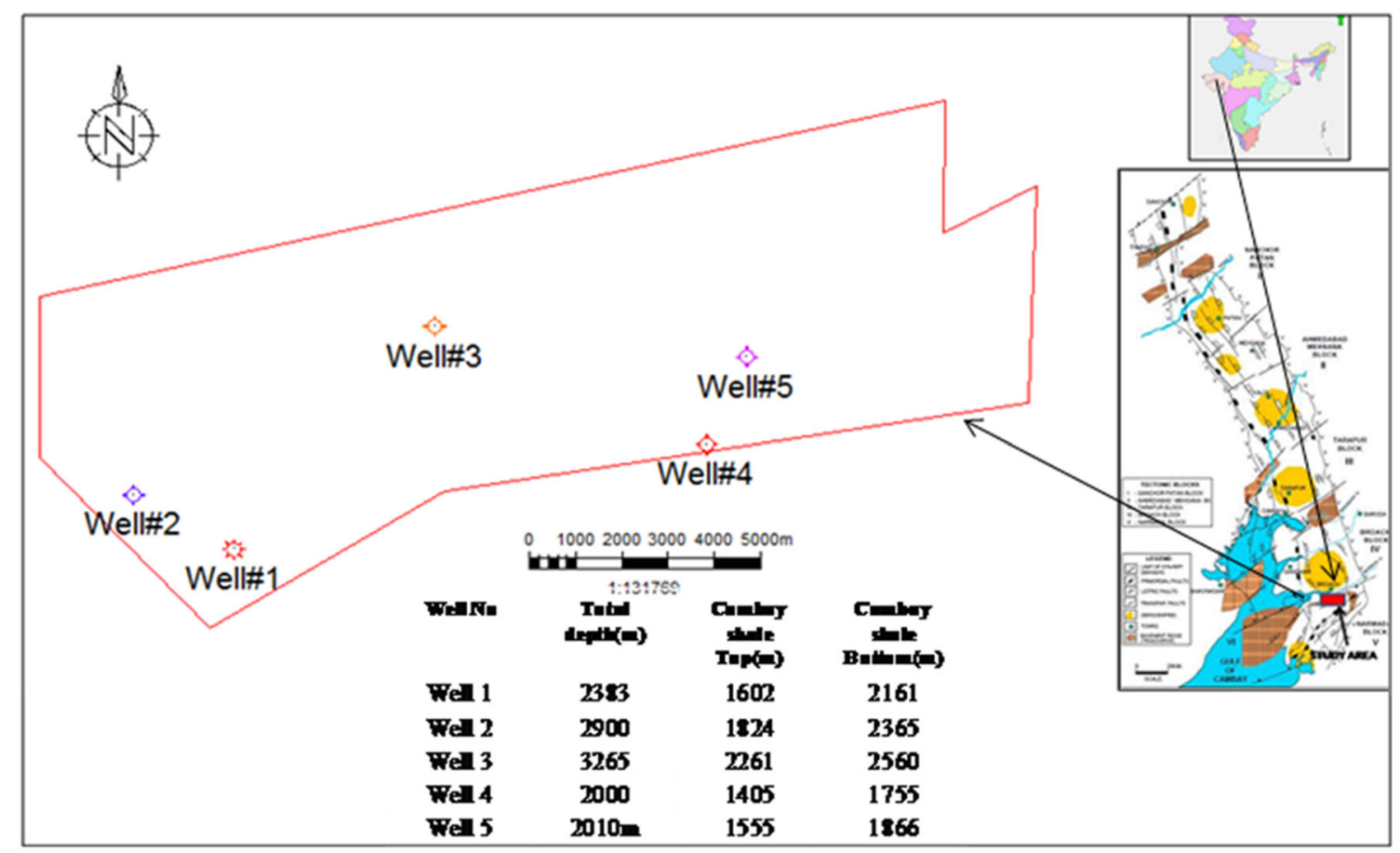

Fig. 1 Location map of the study area shows the five drilled well locations, total depth, Cambay shale top and bottom depth within the study area 
drill cuttings (rock chips) as well as from the XRD and FTIR analyses carried on the powder samples of the drill cuttings from well no. 2 and 3. Poisson ratio and Young's modulus are calculated from the sonic log measurements in 4 (well no. 1, 2, 3, 4) wells in the study area from Eqs. 1-3 (Gassmann 1951; Fig. 2) and converted dynamic Young's modulus to static Young's modulus from $E_{\text {static }}=0.83$ $E_{\text {dynamic }}$ (Neville 1997; Salman 2006).

Poisson's ratio $(V)=\frac{V_{p}^{2}-2 V_{s}^{2}}{2\left(V_{p}^{2}-V_{s}^{2}\right)}$

Shear modulus $(G)=\frac{\rho b}{T_{s}^{2}}$
Young's modulus $(E)=2 G(1+V)$

\section{Brittleness}

When a rock is subjected to increasing stress, it passes through three successive stages of deformation: elastic, ductile and brittle. Based on these behaviors, it is possible to classify the rocks into two classes: ductile and brittle. If the rock has a smaller region of elastic behavior and a larger region of ductile behavior, absorbing much energy before failure, it is considered ductile. In contrast, if the material under stress has a larger region of elastic behavior but only a smaller region of ductile behavior, the rock is considered brittle.

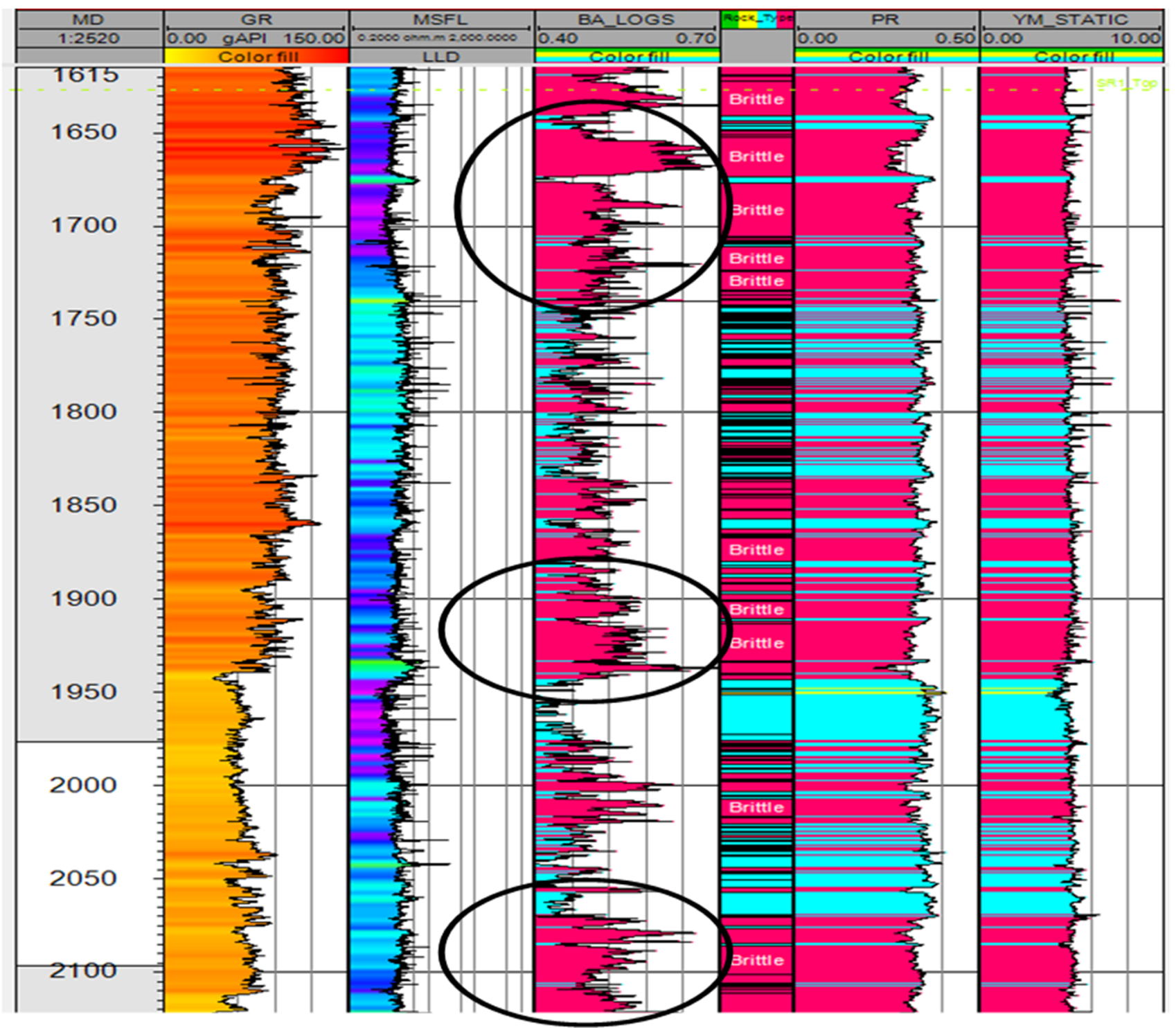

Fig. 2 Graphical representation Young's modulus, Poisson's ratio and brittleness average from logs in well \#1. The encircled depths indicate highly brittle areas 


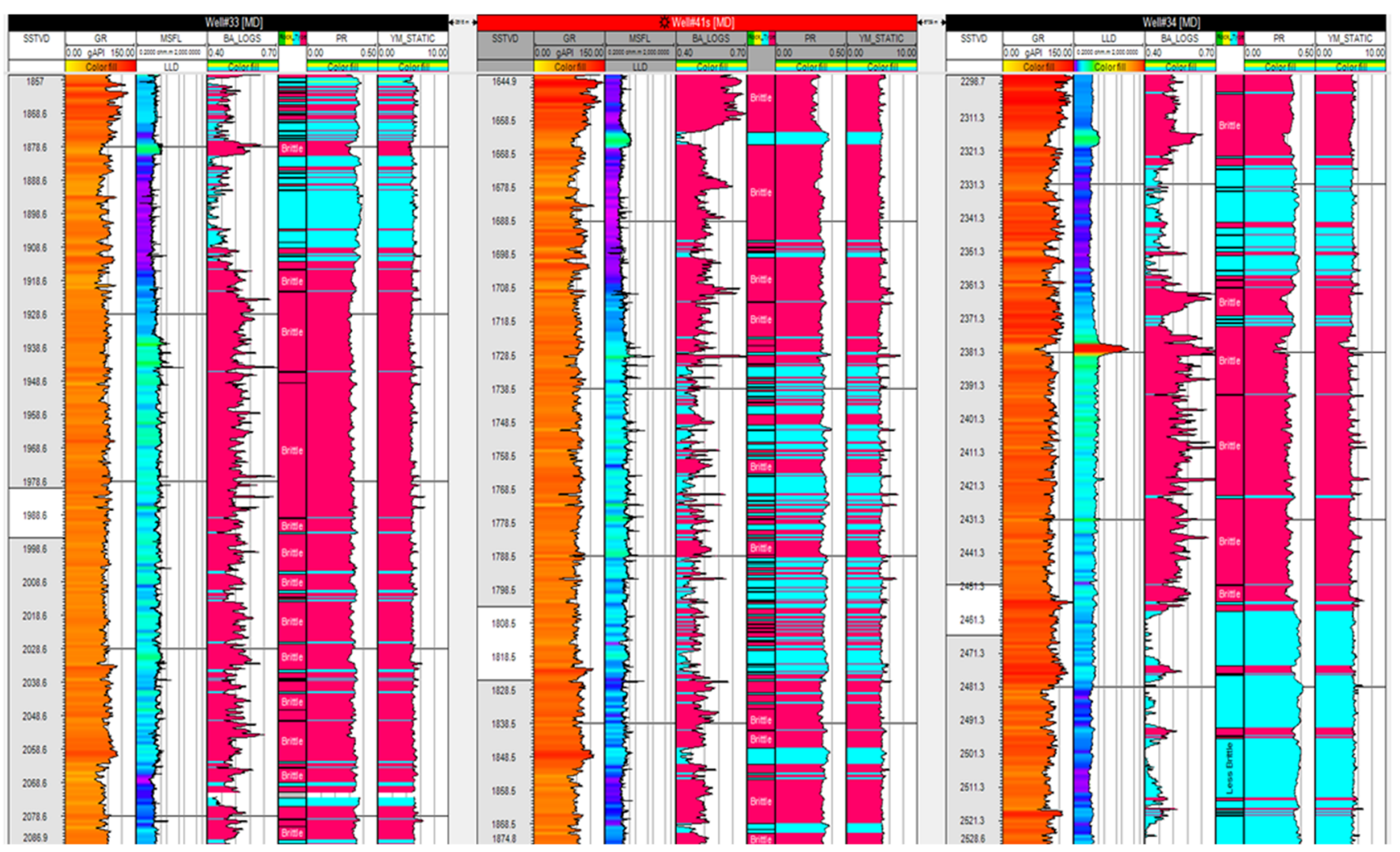

Fig. 3 Graphical representation of BA, PR and static YM in from well logs in the study wells \#1, 2 and 3

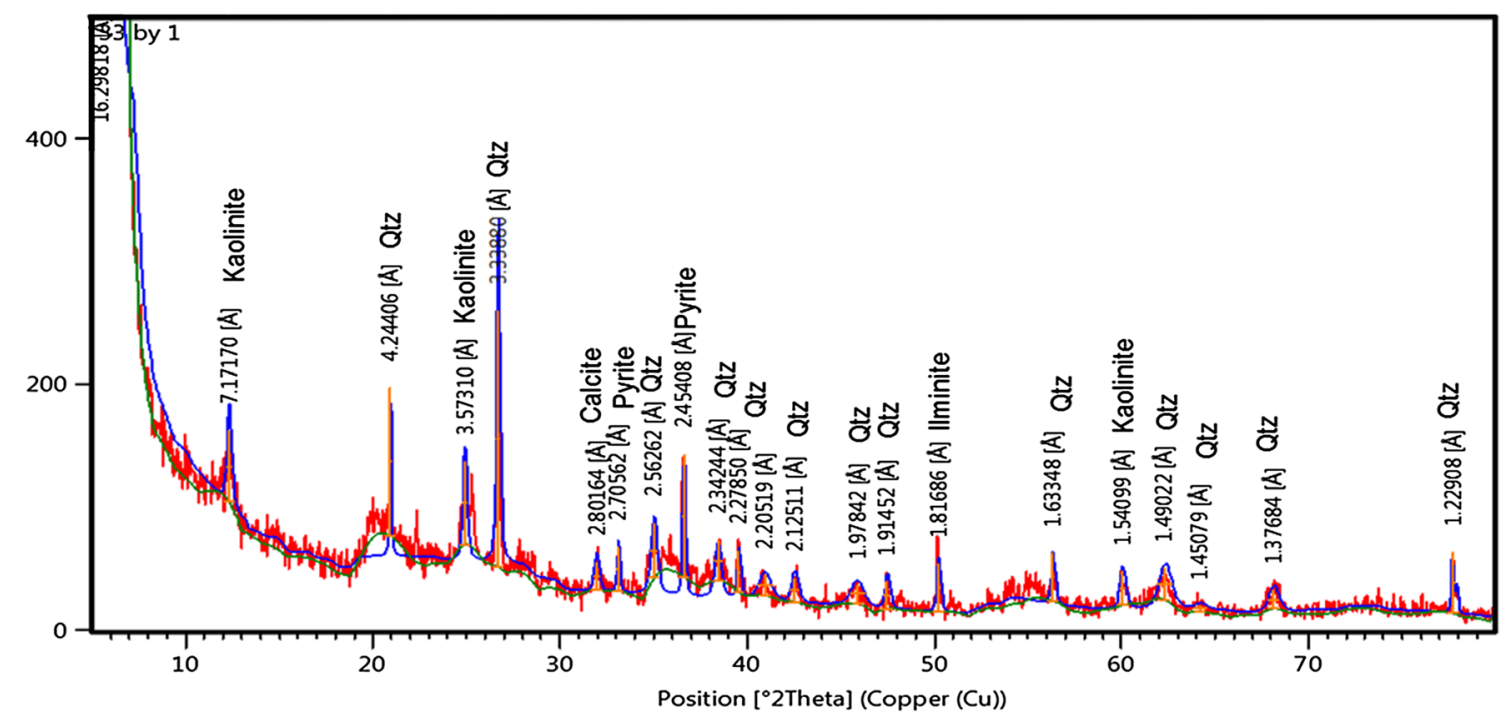

Fig. 4 A representative XRD data analysis and mineral identification from well \#2 in the study area

\section{Brittle average (BA) from logs}

The term brittleness average was proposed by Grieser and Bray (2007) as an empirical relationship between Poisson's ratio and Young's modulus to differentiate ductile from brittle regions. They hypothesize that ductile rocks exhibit low Young's modulus and high Poisson's ratio, while brittle rocks exhibit moderate to high Young's modulus and low Poisson's ratio (Perez and Marfurt 2013, 2014; Salman 2006). Young's modulus and Poisson's ratio (for brittleness) are derived from Eqs. 4, 5, and using the calculated values normalized brittleness average was derived from Eq. 6. 


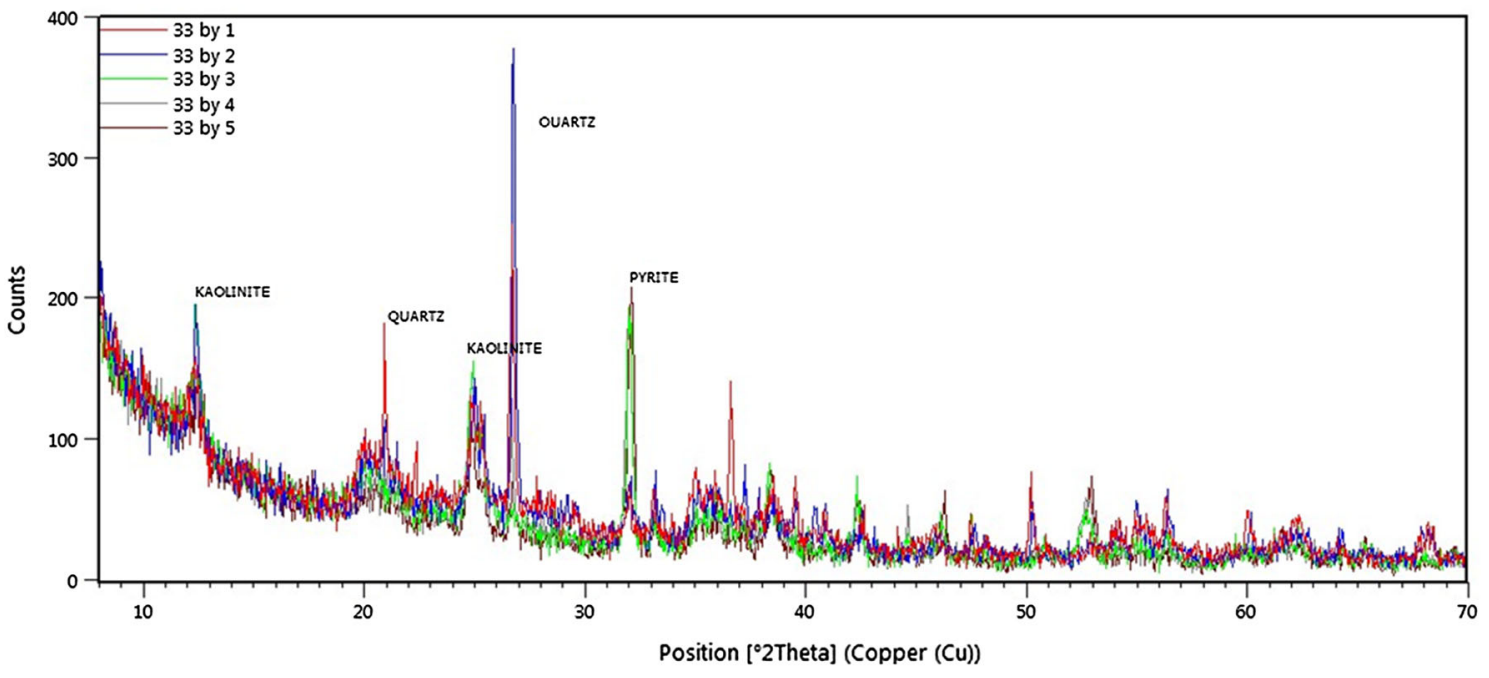

Fig. 5 A representative XRD data analysis and mineral identification from well \#2 from 5 samples in the study area

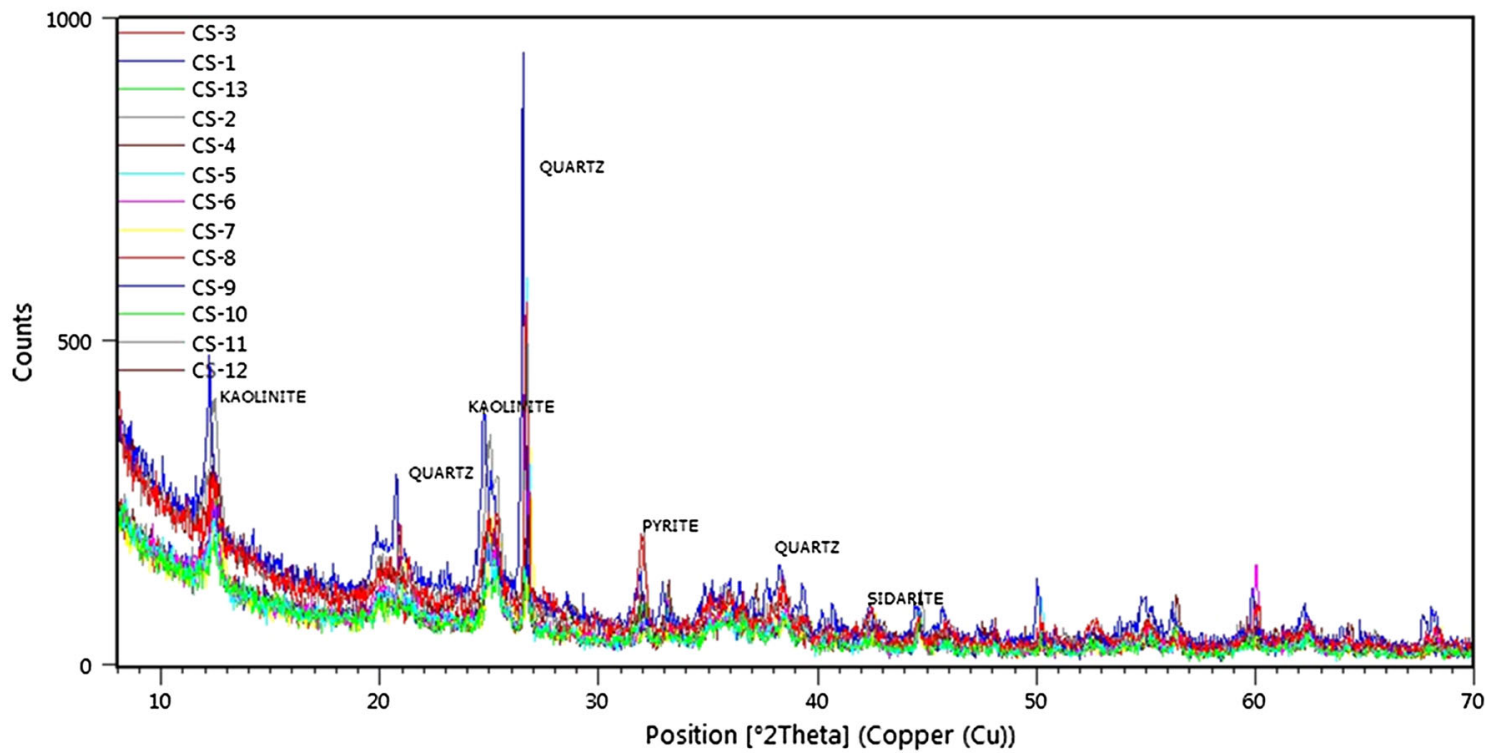

Fig. 6 A representative XRD data analysis and mineral identification from well \#3 from 13 samples in the study area

Young's modulus_brittlenes $=\frac{E-E_{\min }}{E_{\max }-E_{\min }}$

Poisson's ratio_brittleness $=\frac{V-V_{\max }}{V_{\min }-V_{\max }}$

Brittleness average $(\mathrm{BA})=\frac{\left(E_{\text {Brittleness }}+V_{\text {Brittleness }}\right)}{2}$

where $E$ is Young's modulus, and $E_{\min }$ and $E_{\max }$ are the minimum and maximum Young's modulus measured in the logged formation, and where $V$ is Poisson's ratio, and $V_{\max }$ and $V_{\min }$ are the maximum and minimum values of Poisson's ratio logged in the formation. Finally, they define a brittleness average (BA) shown Fig. 2. The Calculation of $\mathrm{BI}$ is extended to all the wells shown Fig. 3.
Brittleness index (BI) from mineralogy

$\mathrm{XRD}$ is a techniques used to examine the chemical composition of rocks. In this technique a rock sample is powdered and irradiated with X-rays of a fixed wavelength. Intensity of the reflected radiation is recorded using a goniometer and gives the composition of the rock.

$\mathrm{X}$-ray diffraction analyses of the samples were performed using a X'Pert PRO, Ultima IV automated powder diffractometer equipped with a copper X-ray source $(45 \mathrm{kV}, 40 \mathrm{~mA})$ and a scintillation X-ray detector. The 10 rock samples were analyzed over an angular range of five to eighty degrees (5-80) two theta. 
Fig. 7 A representative FTIR data analysis and mineral identification from well \#3 in the study area

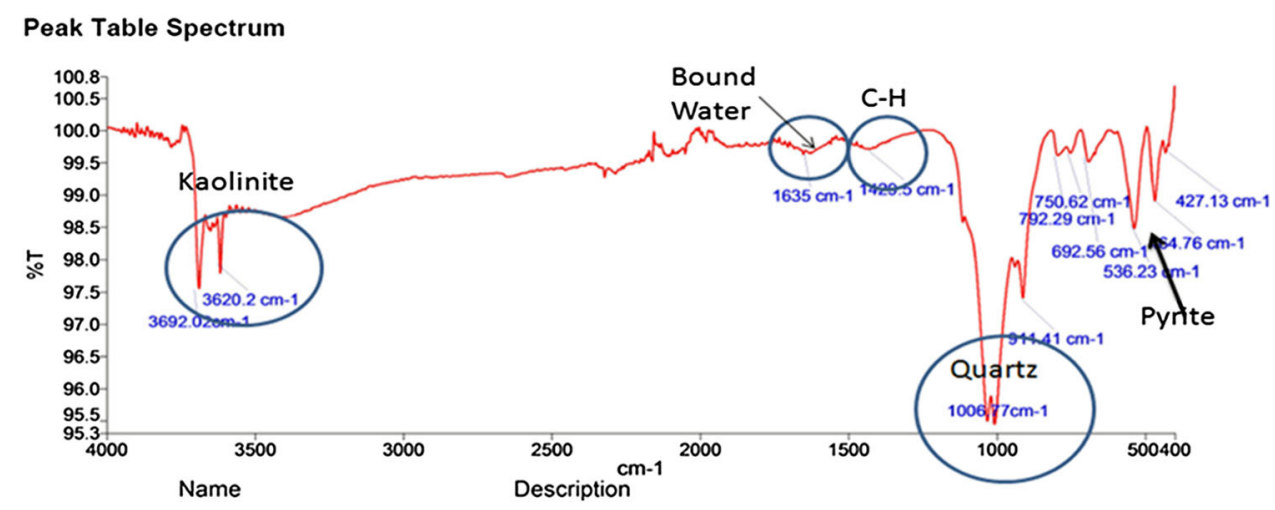

Fig. 8 A representative FTIR data analysis and mineral identification from well \#2 in the study area

Peak Table Spectrum

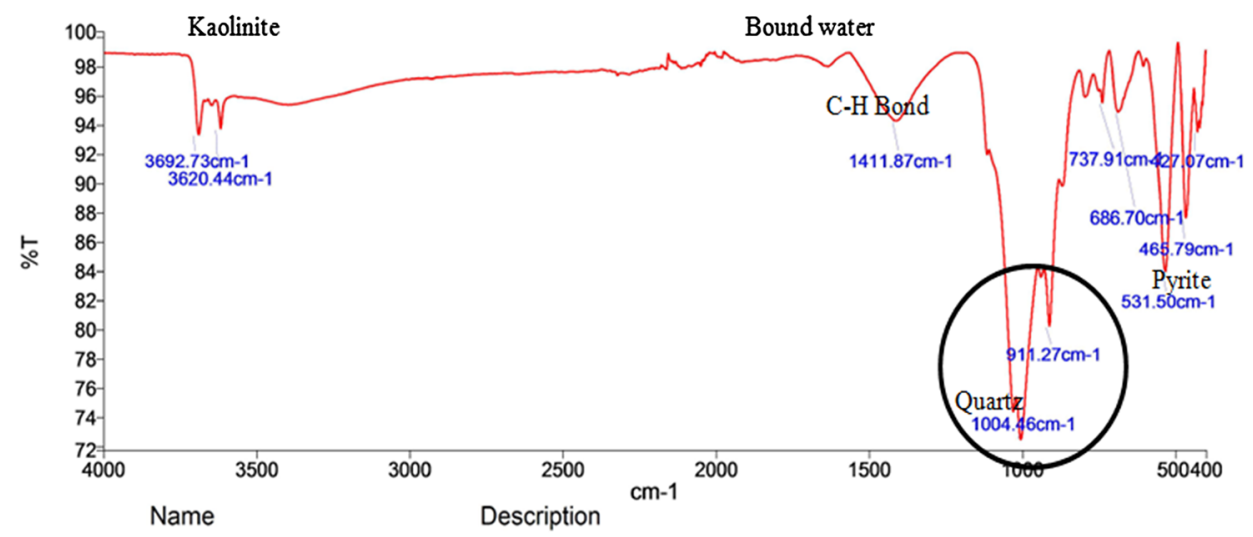

Peak Table Spectrum

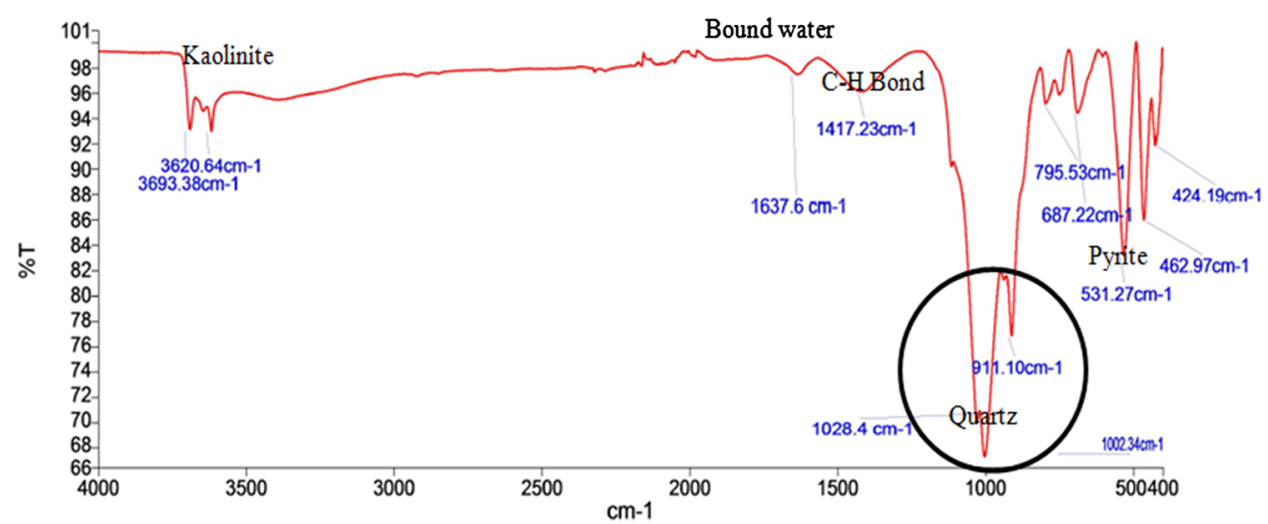

The semiquantitative determinations based on intensity of the major peaks preset in the sample (Fig. 4). The quartz grains have been seen in all the samples to be the main framework grain type. The quartz content ranges from 30 to $69 \%$ of the total rock. Kaolinite, pyrite, calcite and ilmenite are considered to be the second most abundant constituent detrital grains in all the samples, ranging from 1 to $10 \%$. Presence of calcite and halite minerals has also been observed. As per the XRD results, kaolinite is the main clay followed by illite. Among all the clay minerals, kaolinite is consistently present in all the samples. The sample graphical representation of well no 2 is given in Fig. 5, and all the samples correlated each other giving the similar signatures indicate the same type of mineralogy is present in all the samples in well no 2 and well 3 in the study area Figs. 5 and 6 (Srodoi et al. 2001; Nadeau et al. 1984; Morkel et al. 2006; Nayak and Singh 2007).

Fourier transform infrared spectroscopy (FTIR) Spectroscopy is a technique for determining qualitative 
Fig. 9 Thin section showing the presence of organic matter, quartz and clay mineral in the sample of well \#3

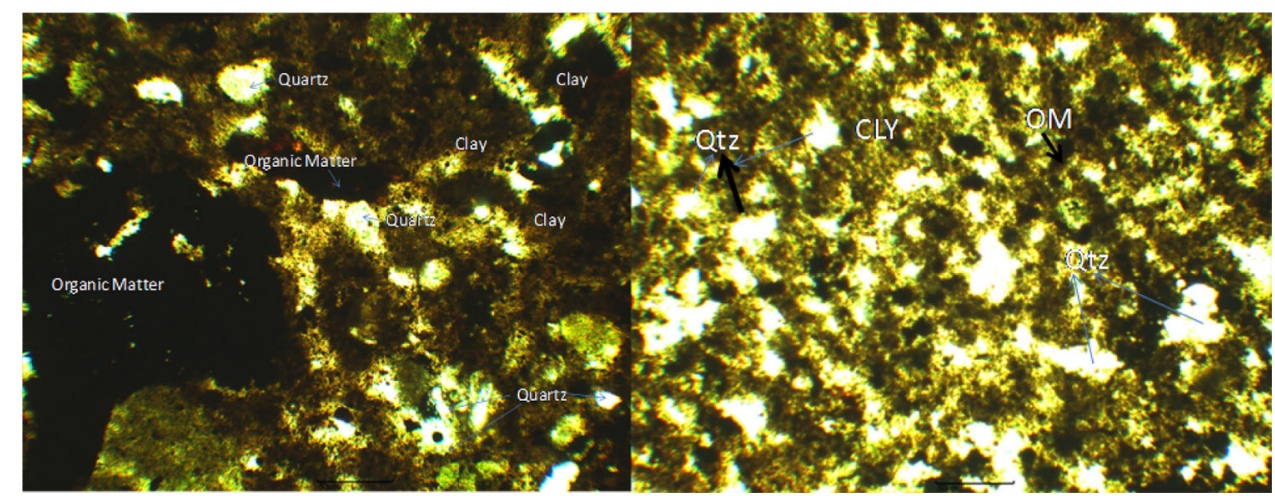

Table 1 Mineralogical composition and mineral-derived BI in the well \#3

\begin{tabular}{lllll}
\hline Depth $(\mathrm{m})$ & Quartz & Clay minerals & Calcite & $\mathrm{BI}=\frac{\mathrm{Qtz}}{\mathrm{Qtz}+\mathrm{Ca}+\mathrm{Cly}}$ \\
\hline $2260-2265$ & 0.574 & 0.164 & 0.07 & 0.710 \\
$2263-2266$ & 0.670 & 0.197 & 0.05 & 0.730 \\
$2266-2269$ & 0.652 & 0.197 & 0.02 & 0.750 \\
$2275-2278$ & 0.521 & 0.369 & 0.03 & 0.566 \\
$2281-2284$ & 0.302 & 0.338 & 0.04 & 0.444 \\
$2284-2287$ & 0.653 & 0.246 & 0.07 & 0.673 \\
$2287-2290$ & 0.606 & 0.313 & 0.05 & 0.625 \\
$2290-2293$ & 0.511 & 0.274 & 0.09 & 0.590 \\
$2305-2310$ & 0.419 & 0.352 & 0.486
\end{tabular}

Fig. 10 BI from mineralogy versus BA log cross-plot in well \#3

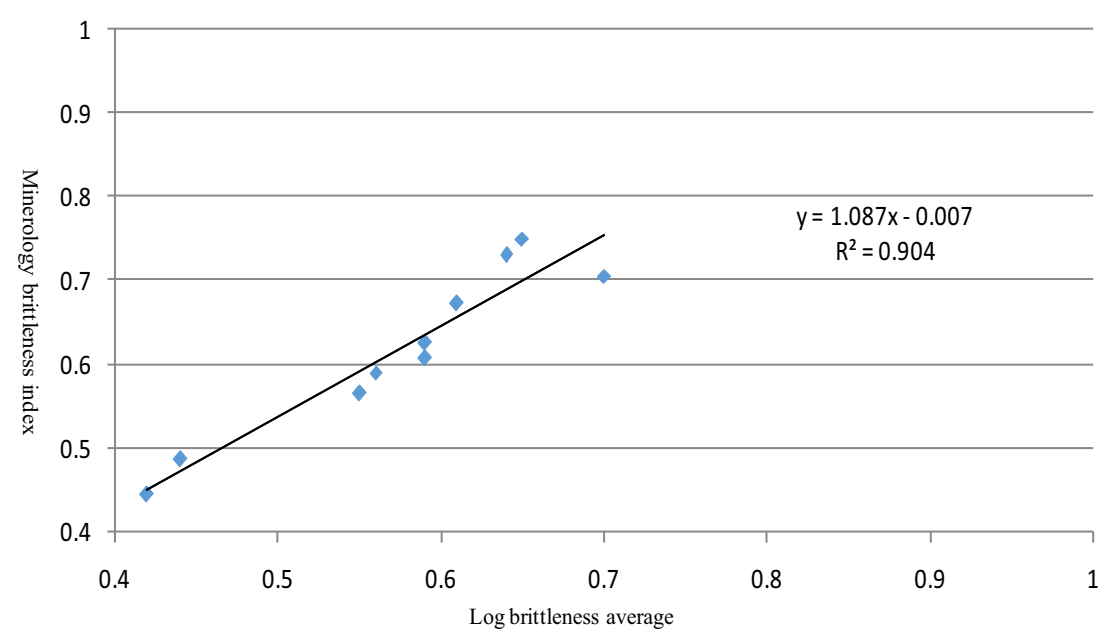

mineral identification. Mineral identification is possible because minerals have characteristic absorption bands in the mid-range of the infrared (4000-400 $\mathrm{cm}^{-1}$ ). The concentration of a mineral in a sample can be extracted from the FTIR spectrum because the absorbance of the mixture is proportional to the concentration of each mineral. The infrared spectra of well \#2 and 3 of Cambay shale samples, presented in Figs. 7 and 8, exhibited
$\mathrm{OH}$ stretching at bands 3620 and $3693 \mathrm{~cm}^{-1}$ and $\mathrm{C}-\mathrm{H}$ stretching at bands 1411 and $1417 \mathrm{~cm}^{-1}$, and the $\mathrm{OH}$ deformation bands were observed at 911 and $911.5 \mathrm{~cm}^{-1}$. Bands associated with $\mathrm{SiO}$ stretching were 692, 994 and $695 \mathrm{~cm}^{-1} ; 753$ and $754 \mathrm{~cm}^{-1}$; and 791 , 795 and $796 \mathrm{~cm}^{-1}$, whereas $\mathrm{SiO}$ deformation bands were 1004, 1032 and $1033 \mathrm{~cm}^{-1}$ (Fig. 9). The same sample in petrography thin sections also showing the quartz and

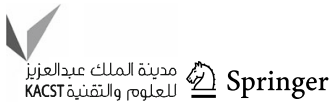




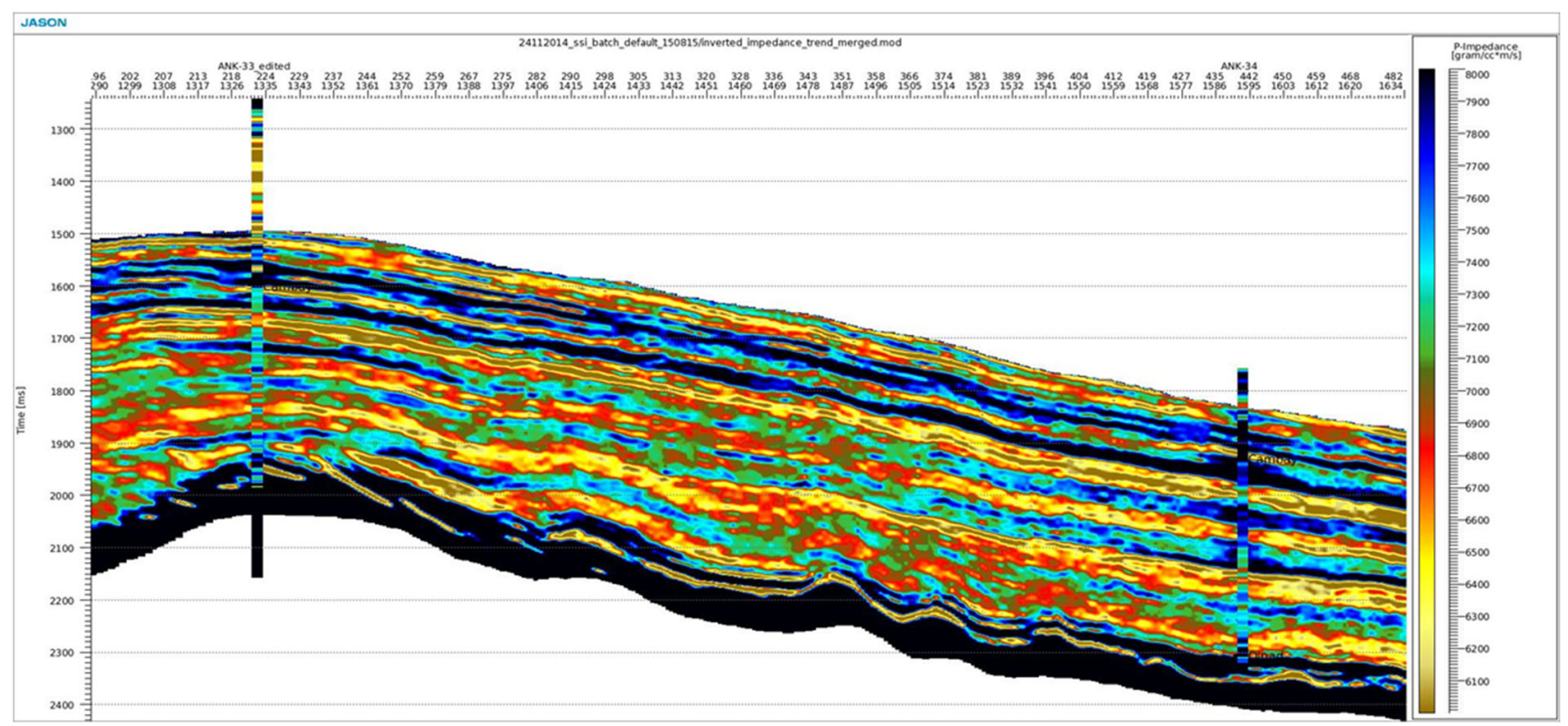

Fig. 11 P-impedance volume cross section along well \#2 and well \#3 in study area

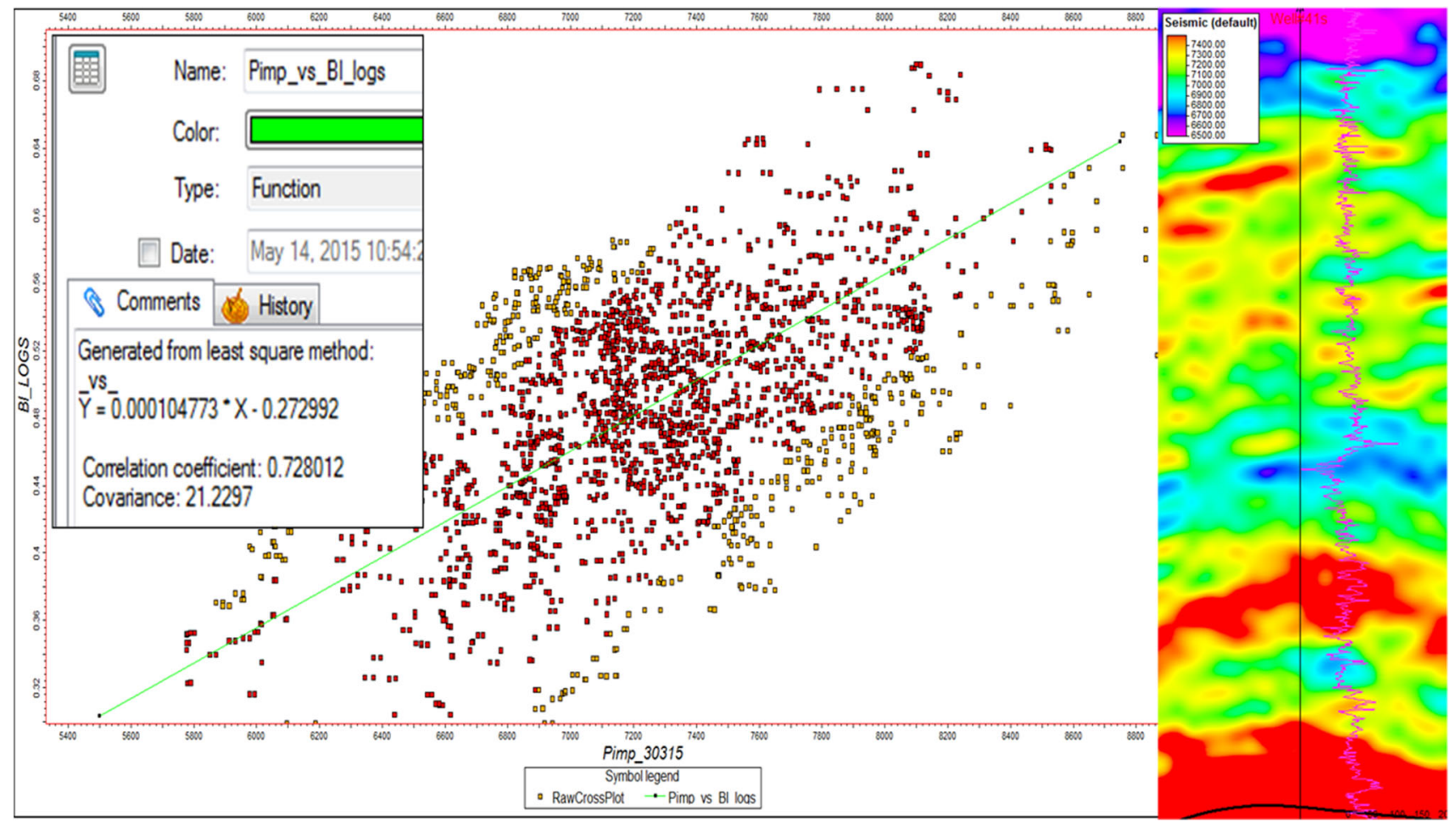

Fig. 12 Cross-plots of P-impedance volume and log-derived BI for establishing the relation the correlation is $72.8 \%$

organic matter presence conforms to the sample containing clay minerals, organic matter and quartz. (Adamu 2010; Djomgoue and Njopwouo 2013).

Jarvie (2007) proposed BI definitions based on the mineral composition of the rock, dividing the most brittle minerals by the sum of the constituent minerals in the rock sample, considering quartz as the more brittle minerals; after Jarvie, some equations, Perez and Marfurt (2013), Nayak and Singh (2007), Altindag (2003), also used the following equation for BI calculation. 


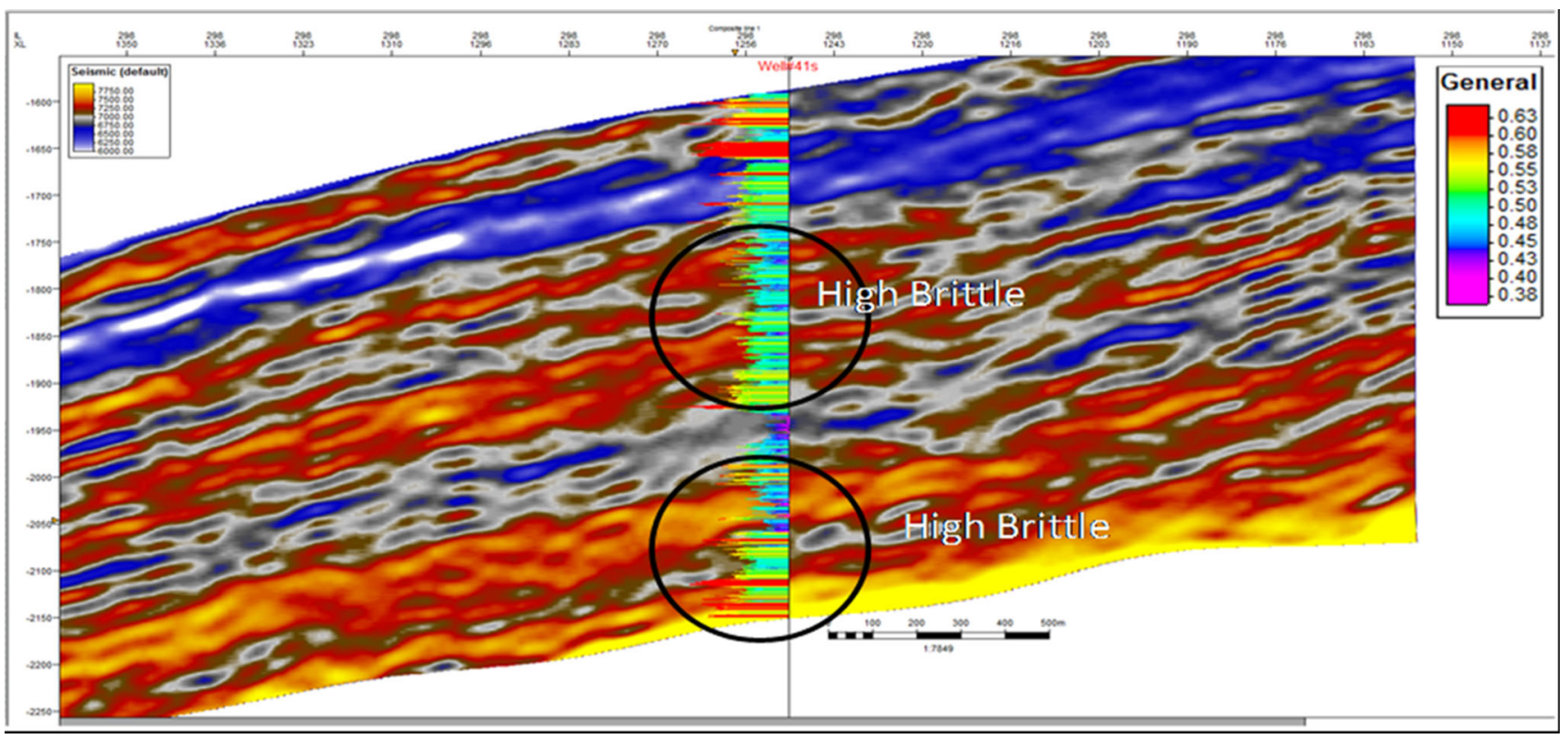

Fig. 13 P-impedance volume and log-derived BI showing in the section

Table 2 Log-derived results in different wells in the study area in Cambay shale section

\begin{tabular}{|c|c|c|c|c|c|c|}
\hline & \multicolumn{2}{|c|}{ Poisson's ratio g API } & \multicolumn{2}{|c|}{ Static Young's modulus (GPa) } & \multicolumn{2}{|c|}{ Brittleness average } \\
\hline & Min & Max & Min & Max & Min & $\operatorname{Max}$ \\
\hline Well-4 & 0.10 & 0.43 & 1.4 & 7.3 & 0.10 & 0.69 \\
\hline Well-3 & 0.20 & 0.41 & 1.3 & 7.54 & 0.10 & 0.72 \\
\hline Well-2 & 0.10 & 0.43 & 1.8 & 6.60 & 0.25 & 0.75 \\
\hline Well-1 & 0.10 & 0.41 & 1.8 & 7.56 & 0.20 & 0.72 \\
\hline
\end{tabular}

Table 3 Log-derived BI in well \#3

\begin{tabular}{llll}
\hline Depth $(\mathrm{m})$ & BI from Lithology & BA from logs & BI from logs from eq. 8 \\
\hline $2260-2265$ & 0.705439484 & 0.7 & 0.7539 \\
$2263-2266$ & 0.730609975 & 0.64 & 0.68868 \\
$2266-2269$ & 0.750207139 & 0.65 & 0.69955 \\
$2275-2278$ & 0.566436986 & 0.55 & 0.59085 \\
$2281-2284$ & 0.444443739 & 0.42 & 0.44954 \\
$2284-2287$ & 0.673085989 & 0.61 & 0.65607 \\
$2287-2290$ & 0.625599688 & 0.59 & 0.63433 \\
$2290-2293$ & 0.590515793 & 0.56 & 0.60172 \\
$2305-2310$ & 0.486610965 & 0.44 & 0.47128 \\
$2330-2335$ & 0.607204966 & 0.59 & 0.63433 \\
\hline
\end{tabular}

Brittleness index (BI) Jarvie (2007) $=\frac{\mathrm{Qtz}}{\mathrm{Qtz}+\mathrm{Ca}+\mathrm{Cly}}$ where Qtz is the fractional quartz content, $\mathrm{Ca}$ the calcite content and Cly is clay content by weight in the rock. In the study area the dolomite is absent. The main observed 


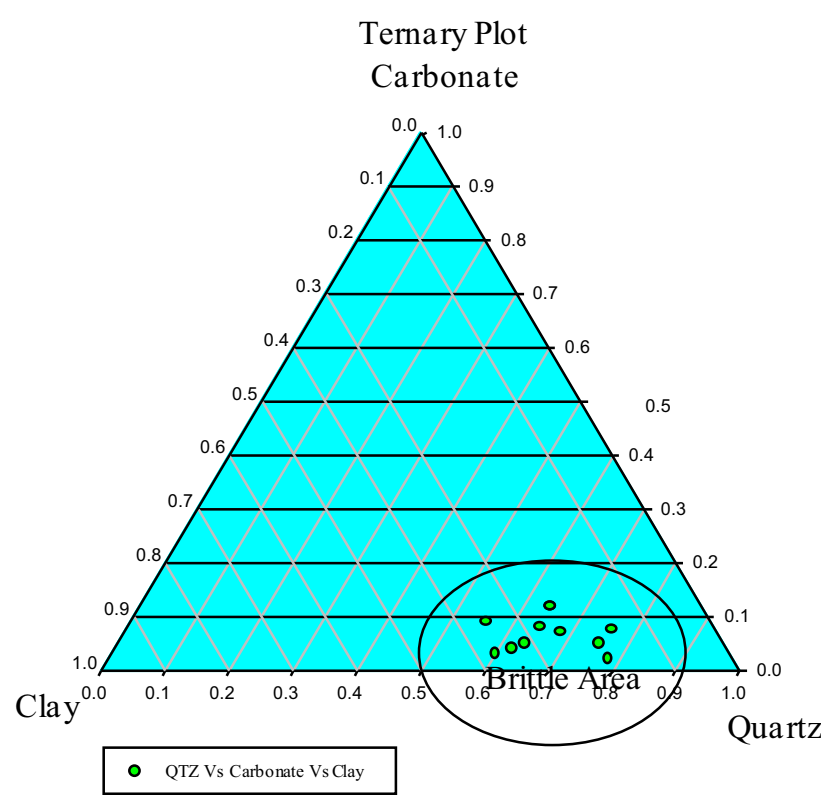

Fig. 14 Ternary diagram results in the study area

Table 4 Rock type classification based on the brittleness index in study area

\begin{tabular}{ll}
\hline Rock BI range & Rock interpretation \\
\hline $0-0.16$ & High ductile \\
$0.16-0.32$ & Low ductile \\
$0.32-0.48$ & Less brittle \\
$\geq 0.48$ & Highly brittle rock \\
\hline
\end{tabular}

mineralogy is quartz, kaolinite, pyrite, siderite and calcite (Fig. 4). The main mineralogy is given in Table 1.

After calculating BI from mineralogy, the log-derived brittleness average (BA) was correlated with BI from XRD data and the brittleness average converted to BI by established Eq. 8 is shown Fig. 10.

$Y=1.087 X-0.007 \quad(Y=B I, X=B A)$

\section{Seismic inversion}

Pre-stack simultaneous inversion estimates P-wave impedance, S-wave impedance and density, which is useful for predicting the lithology and geomechanical behavior of the shale reservoir. Acoustic impedance inversion transforms the seismic reflection data to a acoustic impedance model.
This P-impedance volume is then optimized by modifying the low-frequency trend and enforcing compliance with any additional constraints. P-impedance volume is used as a secondary input in distributing different properties in modeling (Fig. 11; Perez and Marfurt 2014; Harial and Tandon 2012; Angus et al. 2011).

\section{Modeling}

A time-depth relationship was established leading to P-impedance. The cross-plot between BI from logs and P-impedance gives $72.8 \%$ correlation index (Fig. 12).

The established equation from cross-plot helped in modeling the brittleness and identifying high BI areas in the study area (Fig. 13).

$\mathrm{BI}=0.000104773 \times \mathrm{P} \mathrm{imp}-0.272992$

\section{Results}

The sonic $\log$ data of 4 wells, both compressional and shear, were used to compute Poisson's ratio (g API), Young's modulus (GPa) and brittleness average (BA) in Table 2. BA was finally converted to BI values using the derived equation no 1, 2 and 3 (Table 3 ).

After calculating BI from logs and mineralogy, rocks are classified into four categories based on Perez and Marfurt (2014) which are (a) high ductile, (b) less ductile, (c) less brittle and (d) high brittle. The ternary plot shows high quartz content and more brittle area from the XRD data (Fig. 14 and Table 4).

Figures 15 and 16 shows a log correlation in the study area, differentiating brittle and ductile areas in the well section. Log-derived BI was validated by comparing with XRD-derived value. A relationship between BI log and P-impedance was established, and a brittleness model was prepared in the study area for Cambay shale formation.

\section{Conclusions}

Brittleness is considered to be one of the important mechanical properties of shale rocks for hydraulic fracturing. In this study, sonic data were used for calculating BI of Cambay shale section.

In the Cambay shale zones, Young's modulus static (YME) varies between 1.4 and $7.54 \mathrm{GPa}$, whereas the 

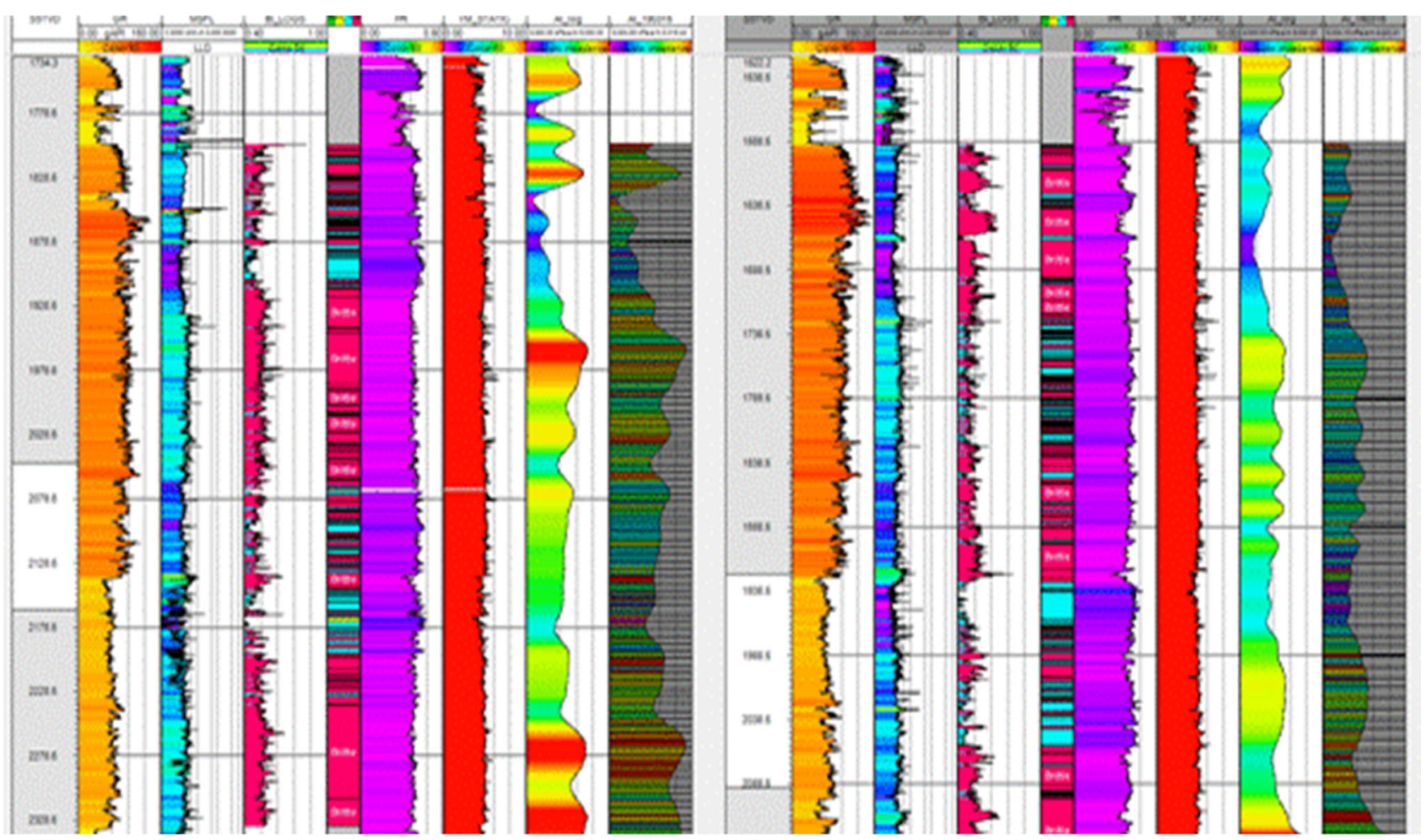

Fig. 15 The Brittleness Index correlation in the study area wells; the red is indicating high brittleness and blue is indicating ductile area in well\#1 and well\#2

Fig. 16 The Brittleness Index modeling output along the study wells in the study area in Cambay shale section

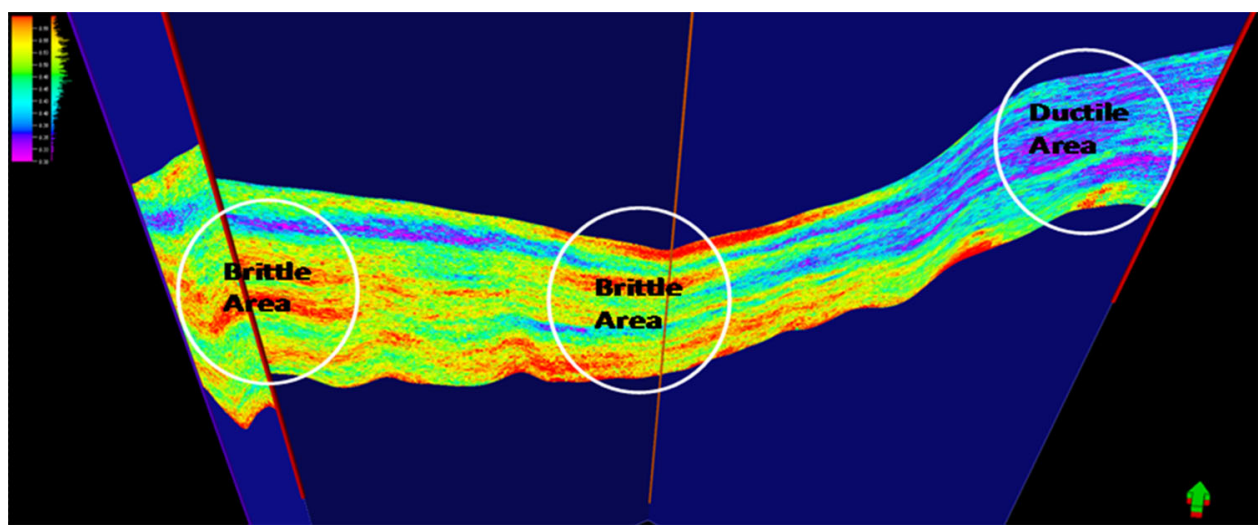

Poisson's ratio (PR) ranges from 0.10 to $0.43 \mathrm{~g}$ API. The $\mathrm{BI}$ range is $0.44-0.75$ in the study area. The well data results were transformed into seismic study by using the VSP check-shot data. This resulted in establishing a relation between seismic P-impedance and BI logs and established relation equation.
The complete study area was modeled by using Eq. 9, and areas of high brittleness were identified in the Cambay shale section. The brittleness derived from logs and brittleness from the model show very good correlation index (Fig. 17).

The information about the BI shell is useful for effective stimulation and leading to better production. 


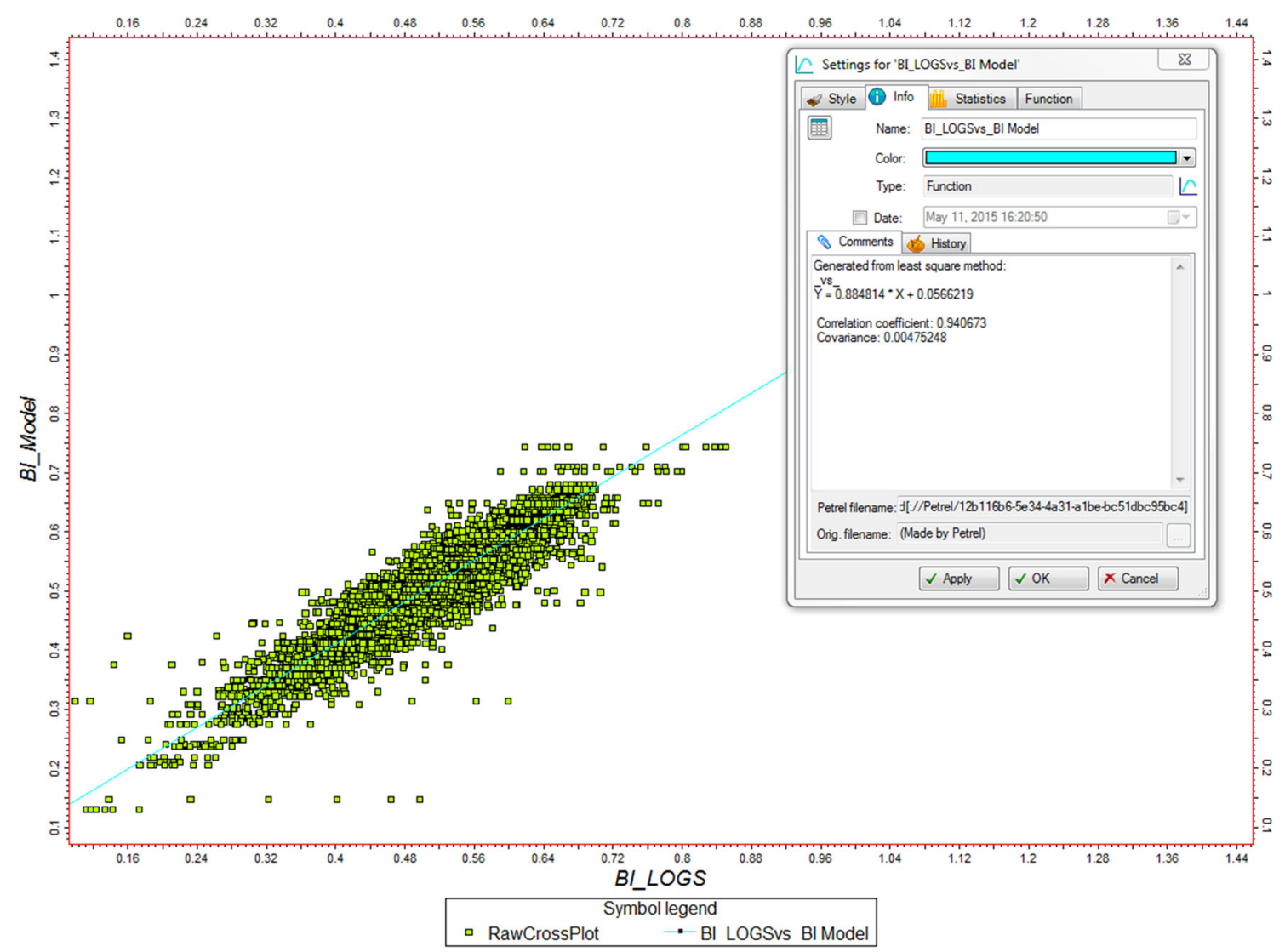

Fig. 17 Relation between the BI logs and BI model; the correlation is 94\%

Analysis shows that the northeastern part of the study area is ductile shale as compared to northwestern part of the study area.

Acknowledgement The authors wish to acknowledge Sudhanshu Bakshi (SVP, Petrophysics) and Mr. Uttam Gupta (Manager, Geophysics) for their active support and also acknowledge GSPC and PDPU management for providing necessary facilities for preparing the manuscript.

Open Access This article is distributed under the terms of the Creative Commons Attribution 4.0 International License (http:// creativecommons.org/licenses/by/4.0/), which permits unrestricted use, distribution, and reproduction in any medium, provided you give appropriate credit to the original author(s) and the source, provide a link to the Creative Commons license, and indicate if changes were made.

\section{References}

Adamu MB (2010) Fourier transform infrared spectroscopic determination of shale minerals in reservoir rocks. Niger J Basic Appl Sci 18(1):6-18

Altindag R (2003) Correlation of specific energy with rock brittleness concepts on rock cutting. J South Afr Inst Min Metall 103(03):15-25
Angus A, Verdon QJ, Fisher QJ, Kendall JM, Segura JM, Kristiansen TG, Crook AJL, Skachkov S, Dutko MJ (2011) Integrated fluidflow, geomechanics and seismic modelling for reservoir characterisation. CSEG Rec 36(05):27-36

Chowdhary LR (2004) Petroleum geology of the Cambay Basin. Indian Petroleum Publishers, Dehradun, pp 1-193

Djomgoue P, Njopwouo D (2013) FT-IR spectroscopy applied for surface clays characterization. J Surf Eng Mater Adv Technol 3:275-282

Gassmann F (1951) Elastic waves through a packing of spheres. Geophysics 16:673-685

Grieser WV, Bray JM (2007) Identification of production potential in unconventional reservoirs. Production and Operations Symposium, Oklahoma City, Oklahoma, USA. doi:10.2118/106623-MS

Harial K, Tandon AK (2012) Unconventional Shale-gas plays and their characterization through 3-D seismic attributes and logs. In: 9th biennial international conference and exposition on petroleum geophysics. Hyderabad, pp 1-4

Jarvie DM, Ronald J, Hill Tim E, Ruble TE, Richard M, Pollastro RM (2007) Unconventional shale-gas systems: the Mississippian Barnett Shale of north-central texas as one model for thermogenic shale-gas assessment. AAPG Bull 91(4):475-499

Mishra S, Patel BK (2011) Gas shale potential of Cambay formation, Cambay Basin, India. Geo-India, New Delhi, pp 1-6

Morkel J, Kruger SJ, Vermaak MKG (2006) Characterization of clay mineral fractions in tuffisitic kimberlite breccias by X-ray diffraction. J South Afr Inst Min Metall 106:397-406

Nadeau PH, Wilson MJ, Mchardy MJ, Tait JM (1984) Interparticle diffraction: a new concept for interstratified clays. Clay Miner 19:757-769 
Nayak PS, Singh BK (2007) Instrumental characterization of clay by XRF, XRD and FTIR. Indian Acad Sci 3:235-238

Neville AM (1997) Properties of concrete, 4th edn. Wiley, New York, pp $1-783$

Perez R, Marfurt K (2013) Calibration of brittleness to elastic rock properties via mineralogy logs in unconventional reservoirs oral presentation given at AAPG international conference and exhibition. Cartagena, Colombia, pp 1-32

Perez R, Marfurt K (2014) Mineralogy based brittleness prediction from surface seismic data: Application to the Barnett Shale. Interpretation 2(04):1-17

Salman MM (2006) The ratio between static and dynamic modulus of elasticity in normal and high strength concrete. J Eng Dev 10(2):813-822
Sarraf SC, Pay DS, Kararia AD, Lal NK (2000). Geology, sedimentation and petroleum systems of Cambay Basin, India. Petroleum Geochemistry \& Exploration in the afro-Asian Region. In: 5th International conference and Exhibition, 25-27 nov-2000, New Delhi. pp.215-226

Sharma RP, Pathak VN, Mohan DM, Gaikwad (2004) Prospect analysis of an area in south Cambay basin: a case study. In: 5th conference and exposition on petroleum geophysics, Hyderabad India, pp 440-445

Srodoi J, Victor A, Drits, Douglas K, Jean M, Hsieh CC, Eberl DD (2001) Quantitative X-ray diffraction analysis of clay-bearing rocks from random preparations. Clays Clay Miner 49(6):514-528 